\title{
Destructive grazing by sea urchins Strongylocentrotus spp. in a central California kelp forest: potential roles of recruitment, depth, and predation
}

\author{
James M. Watanabe, Christopher Harrold \\ Monterey Bay Aquarium, 886 Cannery Row, Monterey, California 93940-1085, USA
}

\begin{abstract}
In January 1986, a sea-urchin mediated deforestation began in Carmel Bay, California, USA, near the center of the California sea otter's range. The deforestation occurred on an offshore rocky reef where depths range from 17 to $>30 \mathrm{~m}$. Both purple (Strongylocentrotus purpuratus) and red ( $S$. franciscanus) sea urchins were abundant and probably belonged to a cohort that settled in 1984. By October 1986, nearly all non-crustose algae had been removed, as were most sessile invertebrates (excluding the cnidarians Balanophyllia elegans and Corynactis californica). Concurrent samples taken from 2 nearby forested sites at comparable depths showed no evidence of overgrazing by urchins. Populations of red sea urchins at the deforested site remained fairly stable, but purple sea urchins declined to zero by July 1989. Algal spores were available during the deforestation, but recruitment of seaweeds did not occur until after sea urchin abundance had declined. Reasons for the decline of the purple sea urchin population are not clear, although predation by sea otters is unlikely. Circumstances surrounding these events indicate kelp forest deforestations may be controlled not only by mortality of adult sea urchins (from predation or disease) and fluctuation of their food supply, but also by factors affecting recruitment such as larval abundance and early post-settlement survival
\end{abstract}

\section{INTRODUCTION}

Forests of giant kelp Macrocystis pyrifera are productive, dynamic comunities in which physical factors such as storms and biological factors such as predation and competition play important roles (see Foster \& Schiel 1985, 1988, Dayton 1985, Schiel \& Foster 1986 , Estes \& Harrold 1988 for recent reviews).

At times, grazing by sea urchins Strongylocentrotus spp. can clear Macrocystis forests of nearly all macroalgae (see Lawrence 1975, Harrold \& Pearse 1987 for reviews). Within kelp forests, sea urchins normally subsist on unattached drift algae. If this food source is reduced, sea urchins may abandon their normally sedentary habit and search actively for food (Harrold \& Reed 1985), concentrating on previously untouched attached plants. Eventually nearly all erect plants are removed, leaving only nongeniculate (encrusting) coralline algae. Sea-urchin mediated deforestations have occurred not only in Macrocystis forests, but also in Laminaria spp. forests world-wide. Once established, deforested areas may persist for prolonged periods (see Lawrence 1975, Harrold \& Pearse 1987).
Several mechanisms can prevent or reverse deforestations. Storms may kill or remove sea urchins outside of protected crevices, keeping populations below levels where deforestations can occur (Cowen et al. 1982, Ebeling et al. 1985). Disease may decimate sea urchin populations in deforested areas, allowing recovery of kelp populations (Pearse \& Hines 1979, Miller \& Colodey 1983, Scheibling \& Stephenson 1984, Scheibling \& Raymond 1990). Increases in alternative food sources, such as diatoms or drift algae from nearby forested areas, may alleviate grazing pressure and allow at least temporary recovery of kelp populations (Duggins 1981a, Harrold \& Reed 1985).

Predation on sea urchins, especially by sea otters Enhydra lutris, also can prevent or reverse deforestations. In the Aleutian Islands, areas inhabited by sea otters have low abundances of sea urchins and high abundances of seaweeds shallower than 16 to $18 \mathrm{~m}$. Areas without sea otters are urchin-dominated with very little or no seaweed biomass (Estes \& Palmisano 1974, Dayton 1975a, Estes et al. 1978). Along the coast of California, range expansion of sea otters has usually been accompanied by reductions of invertebrate graz- 


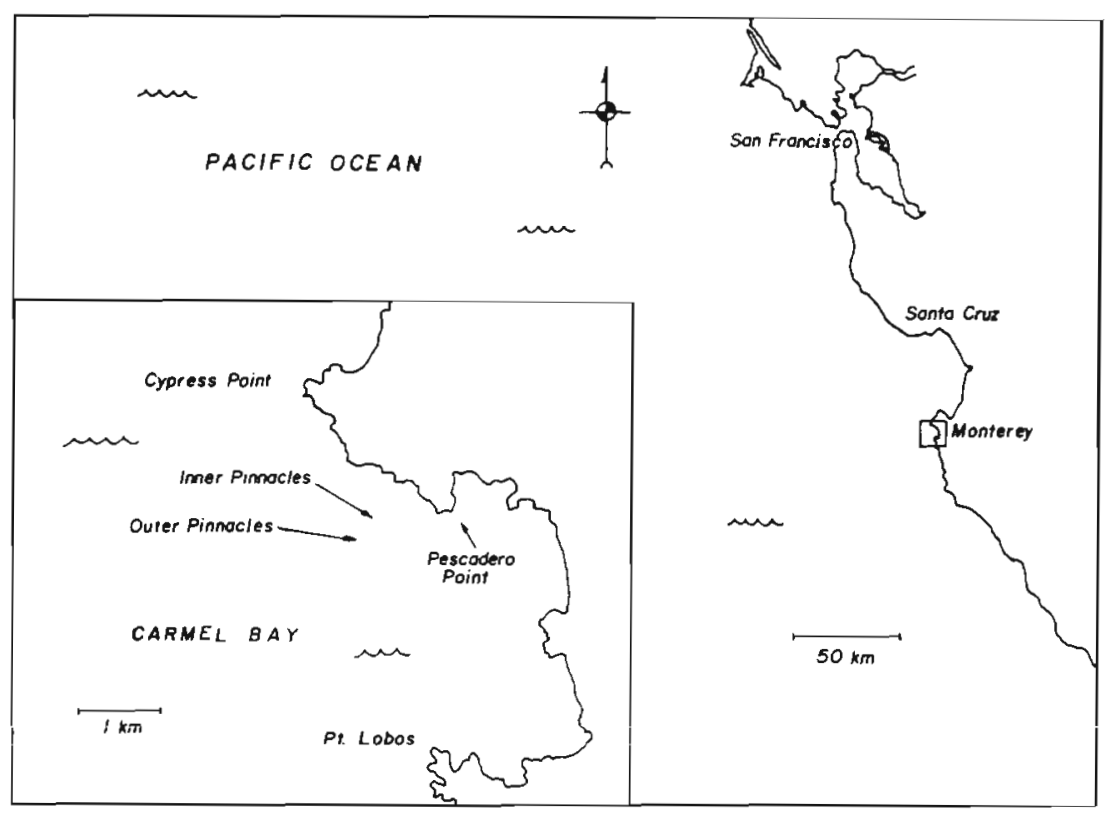

Fig. 1. Location of study sites in northern Carmel Bay, California, USA

ers and increases in algal standing crop (McClean 1962, Lowry \& Pearse 1973, VanBlaricom 1984, Laur et al. 1988; see Riedman \& Estes 1988 for a recent review of sea otter foraging). Duggins (1980) demonstrated in a field experiment that removal of sea urchins (simulating predation by sea otters) resulted in substantial algal recruitment.

However, the mere presence of sea otters does not necessarily result in recovery of kelp populations (Laur et al. 1988), nor does their absence preclude occurrence of healthy kelp forests (Cowen et al. 1982, Foster \& Schiel 1988). In Alaska, sea otters do not control urchin populations below depths of 16 to $18 \mathrm{~m}$ (Estes \& Palmisano 1974, Dayton 1975a, Estes et al. 1978). Rocky reefs with greater spatial heterogeneity or vertical relief also may be less susceptible to overgrazing by urchins, whether or not sea otters are present (Tegner \& Dayton 1981, Cowen et al. 1982, Foster \& Schiel 1988, Laur et al. 1988). The events described in this paper indicate that rarity of successful recruitment of sea urchins alone may affect kelp forest community structure and deforestations along the central Californica coast.

Since sea otters reoccupied the Monterey area in central California in the late 1950 s and early 1960s, populations of sea urchins inhabiting kelp forests have remained small, presumably controlled by intense sea otter predation. Deforestation was thought to be highly unlikely, if not impossible. However, in early 1986 deforestation began in Carmel Bay (Fig. 1), near the center of the California sea otter's range. The data presented in this paper document events at this site and compare them to those at 2 nearby kelp-dominated sites through mid-1989. To our knowledge, this defor- estation is unique within the range of the California sea otter.

\section{MATERIALS AND METHODS}

Study site. The study area is located along the northern end of Carmel Bay, California, USA $\left(36^{\circ} 33^{\prime} \mathrm{N}\right.$, $121^{\circ} 59^{\prime} \mathrm{W}$ ) (Fig. 1). Two reefs were sampled during the study: an offshore reef that became deforested between January and August 1986 ('Outer Pinnacles') and a larger reef located closer to shore where a welldeveloped, though seasonally fluctuating, kelp forest occurred throughout the study ('Inner Pinnacles'). Both reefs were sampled 8 times between August 1986 and July 1989.

The substrate on both reefs is composed of large, high-relief outcrops of granite or basalt. These outcrops are cut by steep-sided surge channels and are surrounded by cobble and sand. The Outer Pinnacles is located 1.6 to $1.7 \mathrm{~km}$ from shore and covers 2 to $3 \mathrm{ha}$. Depths range from $17 \mathrm{~m}$ at the shallowest point to $>30 \mathrm{~m}$. The Inner Pinnacles is located 1 to $1.3 \mathrm{~km}$ offshore and covers 6 to 7 ha (Fig. 1). Depths range from $15 \mathrm{~m}$ to $>30 \mathrm{~m}$ at the seaward edge. For at least 10 yr prior to August 1986, both areas possessed similar multi-layered benthic assemblages of seaweeds and sessile invertebrates (Watanabe pers. obs.). The floating surface canopy was composed primarily of the giant kelp Macrocystis pyrifera, with lesser amounts of the bull kelp Nereocystis luetkeana.

The Outer Pinnacles is exposed to seas and swell from both the south and west and is often subject to strong currents. The Inner Pinnacles is only slightly more protected from westerly swells, but is equally 
exposed to southerly swells. Winter storm waves have been observed breaking over both reefs, despite their substantial depths.

Estimation of surface canopy cover. Surface canopy cover was monitored using infrared aerial photographs (taken by EcoScan, Watsonville, CA), beginning in November 1985. Photographic transparencies were taken from an altitude of $2500 \mathrm{~m}$ within a predetermined range of tide, wind, and sea states. Transparencies were projected onto $1: 28000$ scale baseline maps and the extent of the surface canopy outlined. Canopy area was estimated by overlaying a grid on the maps $(20 \times 20$ per $2.5 \mathrm{~cm})$, counting squares with at least $50 \%$ cover, and converting to hectares.

Status of the surface canopy before 1985 was obtained from aerial photographs taken for the California Department of Fish and Game and the US Fish and Wildlife Service. No area estimates were made from these photographs. However, they do provide evidence regarding presence or absence of surface canopies on both reefs since 1974 .

Population and community structure. Preliminary data were gathered from 2 areas to the Outer Pinnacles in August 1986: one had already lost most of its algal turf; the other contained patches of crustose coralline algae interspersed with more typical algal/invertebrate turf. A single site on the seaward edge of the Inner Pinnacles also was sampled. At all 3 areas, quadrats were placed randomly along $100 \mathrm{~m}$ radii centered at the boat's anchor, which had been dropped haphazardly.

In October 1986, one permanent sampling site was chosen haphazardly at the Outer Pinnacles and 2 at the Inner Pinnacles (each $40 \times 40 \mathrm{~m}$ ). One of the Inner Pinnacles sites was on the seaward edge of the kelp canopy ('Inner Pinnacles Edge') and the other was in the middle of the kelp bed ('Inner Pinnacles Central'). New quadrat locations were chosen for each site and date; quadrats were located randomly within each site. Depth ranges of quadrats were 18 to $29 \mathrm{~m}$ (Outer), 18 to $28 \mathrm{~m}$ (Inner Edge), and 16 to $25 \mathrm{~m}$ (Inner Central).

Density estimates. Selected mobile invertebrates and understory brown algae were counted in $1 \mathrm{~m}^{2}$ quadrats (Table 1). Individuals smaller than $1 \mathrm{~cm}$ were probably under-represented at the Inner Pinnacles where algal/ invertebrate cover was higher, making small individuals more difficult to find. Sample sizes were either 12 or 16 quadrats per site.

Sea urchin size and reproduction. Test diameters of sea urchins collected from $1 \mathrm{~m}^{2}$ quadrats at each site were measured to the nearest millimeter and then released. At the Inner Pinnacles, both large and small urchins were probably undersampled to a slight degree. Some of the small urchins $(<1 \mathrm{~cm})$ were no doubt overlooked and the largest urchins were often nestled deeply in crevices. Attempts to dislodge these individuals usually crushed their tests, making measurement impossible.

Reproductive development was estimated at each site in August 1986, February 1988, September 1988, and June 1989. Five to 20 individuals of each species were collected haphazardly from each site and dissected in the laboratory. A gonad index was calculated for each individual as (blotted wet mass of gonad)/(total wet body mass) $\times 100$. Test diameters ranged from 18 to $68 \mathrm{~mm}$ for Strongylocentrotus purpuratus and 21 to $91 \mathrm{~mm}$ for S. franciscanus.

Percent cover estimates. Percent cover of sessile invertebrates and small benthic algae was estimated in situ or from photographs. From August 1986 through February 1988 ( 6 censuses) in situ estimates were made from 24 random points in a $1 \mathrm{~m}^{2}$ circular plot (12 radii, 2 points per radius). Organisms directly under each point or intersecting an imaginary vertical line $1 \mathrm{~m}$ above it were recorded, making possible values of percent cover exceeding $100 \%$.

Table 1. Mobile invertebrates and understory brown algae counted in $1 \mathrm{~m}^{2}$ density quadrats. Juvenile Macrocystis were arbitrarily defined as plants < $1 \mathrm{~m}$ tall; kelp sporelings were small brown blades that could not be identified to species. "Taxa sufficiently abundant to analyze statistically

ECHINODERMATA (Echinoidea) Strongylocentrotus franciscanus"

Strongylocentrotus purpuratus*

ECHINODERMATA (Asteroidea)

Asterina (Patiria) miniata.

Dermasterias imbricata.

Pisaster giganteus

Pycnopodia helianthoides

MOLLUSCA (Archeogastropoda)

Astraea gibberosa*

Calliostoma spp.

Tegula spp.

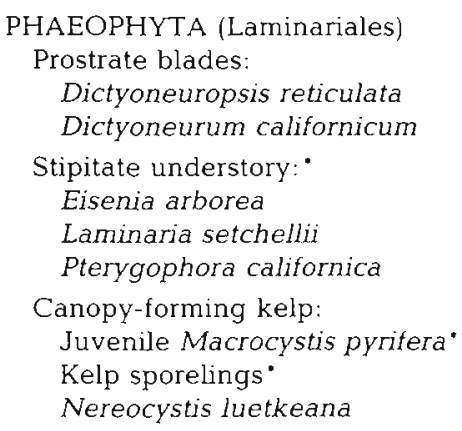


In September 1988, we began using photographs to reduce diving time at greater depths. Photographs were taken with a camera attached to a $1 \mathrm{~m}^{2}$ framer. The change in methods did not result in unreasonable shifts in percent cover estimates nor in number of taxa encountered (e.g. Figs. 9 to 13 between February and September 1988). The number of points sampled per quadrat was increased from 24 to 50 , increasing the chance that taxa hidden beneath overstory taxa would still be encountered elsewhere in the photograph. Although underlying taxa would still be underestimated, this loss in resolution was offset by increased diver safety, which was of greater concern. Fifty uniformly distributed points were sampled from each photograph using a dissecting microscope with an ocular grid. Although not a true random method, bias would be introduced only if the organisms were distributed at the same spatial scale as the grid. This was not the case in any of the photographs. Sample size was 10 quadrats per site (except August 1986, when N's ranged from 11 to 22 per site).
Spore availability and algal recruitment. To test whether lack of recovery of kelp populations at the deforested site was the result of insufficient spore settlement, 5 recruitment samplers were deployed at each site in August 1987. Each sampler consisted of $1.5 \mathrm{~m}$ of polypropylene line attached to an eyebolt and suspended above the substrate by a float. The vertical orientation and small diameter of each sampler made it difficult for sea urchins to climb the line or graze its surface. The samplers were retrieved from the Inner Central site after 6 mo and from the other 2 sites after $8 \mathrm{mo}$. In the laboratory, each line was examined under a magnifying fluorescent lamp and all individual brown algae were counted. Most plants were large enough to identify to genus.

Statistical analyses. Percent cover and density data were analyzed using a mixed model 2-way analysis of variance (ANOVA) with site as a fixed factor (3 levels) and date as a random factor ( 7 levels). Data collected in August 1986 were not included in these analyses because sampling at the Inner Pinnacles Central site did not begin until October 1986. Gonad index data

Table 2. Species included in categories lumped together for statistical analyses. - Taxa whose mean percent cover exceeded $5 \%$ on at least one of the 8 census dates. Species of nongeniculate (encrusting) coralline algae were not distinguished in the field

COMPOUND ASCIDIANS
Aplidium californicum
Aplidium solidum
Archidistoma psammion
Archidistoma ritteri
Cystodytes lobatus
Didemnum carnulentum
Diplosoma macdonaldi
Euherdmania claviformis
Metandrocarpa taylori
Perophora anectens
Polyclinum planum
Pycnoclavella stanleyi
Trididemnum opacum
ERECT BRYOZOANS
Crisia spp.
Costazia robertsonae
Diaperoecia californica
Heteropora magna
Hippodiplosia insculpta
Lagenipora spp.
Phidolopora pacifica
Thalamoporella californica
ENCRUSTING SPONGES
Acarnus enthacus
Cliona spp.
Hymenamphiastra cyanocrypta
Leucandra heathi
Microciona spp.
Spheciospongia confoederata
Tethya aurantia
Stelletta clarella
Unidentified encrusting sponge

COMPOUND ASCIDIANS

Aplidium solidum

Archidistoma psammion

Archidistoma ritter

Didemnum carnulentum

Metandrocarpa taylori

Polyclinum planum

Pycnoclavella stanleyi

didemnum opacum

Crisia spp."

Costazia robertsonae

Heteropora magna

Lagenipora spp.

Phidolopora pacifica

NCRUSTING SPONGES

Acarnus enthacus

Hymenamphiastra cyanocrypta

Leucandra heathi

Microciona spp.

Tethya aurantia

Unidentified encrusting sponge (several species)

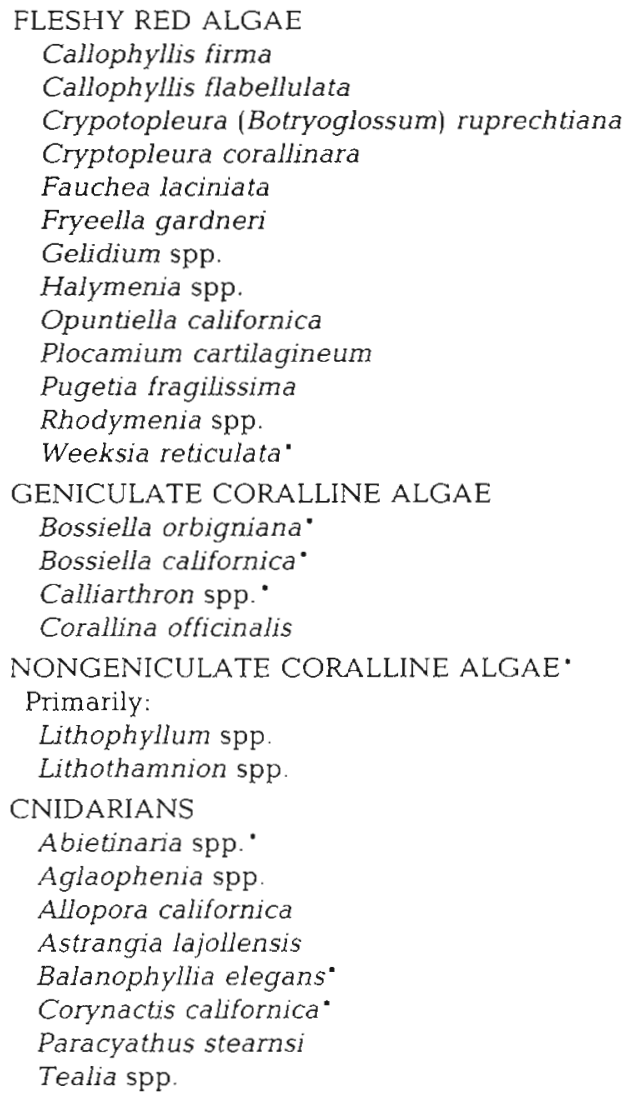


and kelp recruitment data were analyzed by one-way ANOVA with site a fixed factor (3 levels).

All tests were conducted at the 0.05 level, unless otherwise indicated. Before analysis, homogeneity of variances was determined using Cochran's Test (Winer 1971). If variances were heterogeneous, density and kelp recruitment data were transformed using $\log (x+1)$ or Taylor's Power Law (Elliott 1977), whichever resulted in a non-significant Cochran's Test. Percent cover and gonad index data were subjected to an arcsine transformation $\left(2 \sin ^{-1} p\right.$, where $p=$ proportion, Sokal \& Rohlf 1981) if variances were heterogeneous.

Variances of several variables remained heterogeneous after transformation. Most of these instances occurred when mean abundance (and variance) of a taxon was zero at the Outer Pinnacles on several sampling dates. Comparisons among sites were still carried out, but at the 0.01 level. A non-significant result would still be valid (Underwood 1981) and the test is conservative with regard to differences among sites. However, marginally significant results should be interpreted with caution where variances are heterogeneous. Non-parametric tests were not an alternative because they too depend on homogeneity of variation among groups (Underwood 1981).

The multiple comparison of interest was the Outer Pinnacles vs the combined mean of the Inner Pinnacles sites (i.e. comparing the deforested site with the average of the 2 forested sites). If the site-by-date interaction was not significant (conservatively, $p>0.20$ ), overall site means (all dates combined) were compared. If a significant interaction was present, the site comparisons were carried out for each date separately. In these instances, experimentwise error was maintained by using the Dunn-Sidák method to determine critical values $\left(\right.$ alpha' $=1-(1-\text { alpha })^{1 / k}$, where $k=$ number of planned comparisons (Sokal \& Rohlf 1981); in this instance $k=7$ (one for each date analyzed) and alpha' $=0.007$, or 0.001 if variances were heterogeneous).

Sample sizes for the density data were either 16 (October 1986 through August 1987) or 12 (February 1988 through July 1989). In order to avoid dependency of cell means and interactions inherent in a non-orthogonal design (Winer 1971, Wilkinson 1988), 4 quadrats were randomly deleted from all dates where $\mathrm{N}=16$, equalizing all N's to 12 . For the 10 species treated in this manner (see Table 2), correlation coefficients of means of the reduced data set and the full data set varied from 0.86 to 0.99 , with a median of 0.98 .

Due to the large number of species encountered in the point-contact quadrats and the infrequent occurrence of most of them, species were lumped into higher taxonomic or functional categories prior to statistical analysis (Table 2).

\section{RESULTS}

\section{Surface canopy cover}

A well-developed surface canopy is visible in aerial photographs of both Outer Pinnacles and Inner Pinnacles taken in late summer or early fall of 1974 to 1976 and 1981 to 1984 . The only winter photograph (January 1975) shows no surface canopy at either site. A welldeveloped summer canopy and a sparse or absent winter canopy is typical of central California kelp forests (e.g. Cowen et al. 1982, authors' unpubl. data).

Since November 1985, seasonal oscillation of the surface canopy has occurred at the Inner Pinnacles, varying from peaks of 3.5 to 5.5 ha to less than 0.5 ha (Fig. 2). Annual minima occurred as early as January (1987) and as late as June (1986; Fig. 2). In contrast, the canopy at the Outer Pinnacles was absent between March 1986 and September 1989 (Fig. 2). In September 1989 less than 0.1 ha of canopy appeared, but it was gone by November. Based on the pre-1985 aerial surveys, such a prolonged absence of kelp from this site has not occurred since at least 1974 .

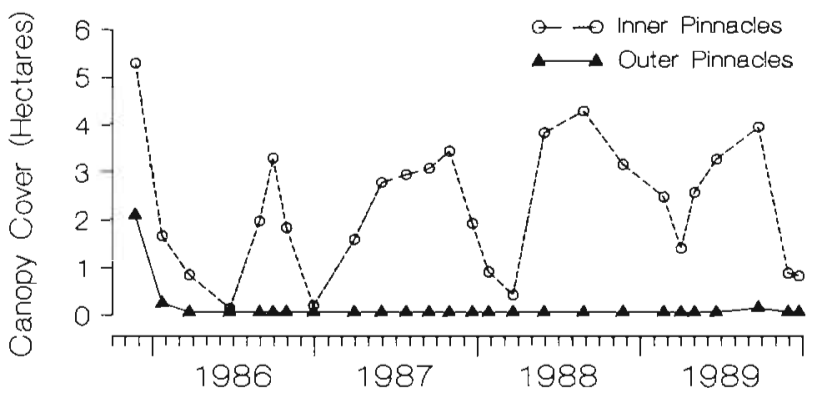

Fig. 2. Surface canopy cover of kelp at Outer Pinnacles and Inner Pinnacles, estimated from infrared aerial photographs
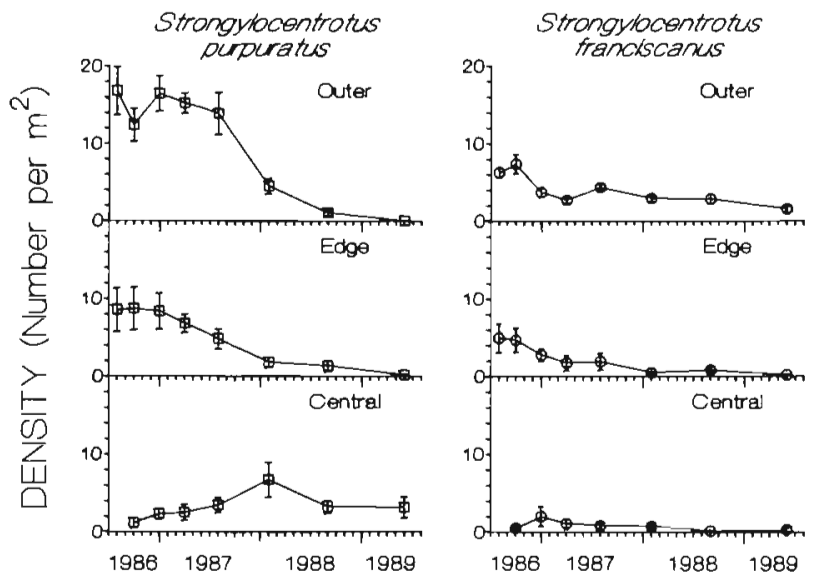

Fig. 3. Strongylocentrotus spp. Densities of purple and red urchins. Error bars are \pm one standard error of the mean. Outer refers to the Outer Pinnacles; Edge and Central refer to the 2 Inner Pinnacles sites 
Table 3. Two-way ANOVA of density data (SITE fixed, DATE random). Where variances were heterogeneous, critical p-values = 0.01 ; otherwise 0.05 . When site-by-date interactions were significant $(p<0.20)$, multiple comparisons were made for each date separately; critical p-values for individual dates were 0.007 (0.001 if variances were heterogeneous; see 'Materials and methods').

For Cochran's Test, $\cdot \mathrm{p}<0.05, \cdots \mathrm{p}<0.01$, ns: not significant

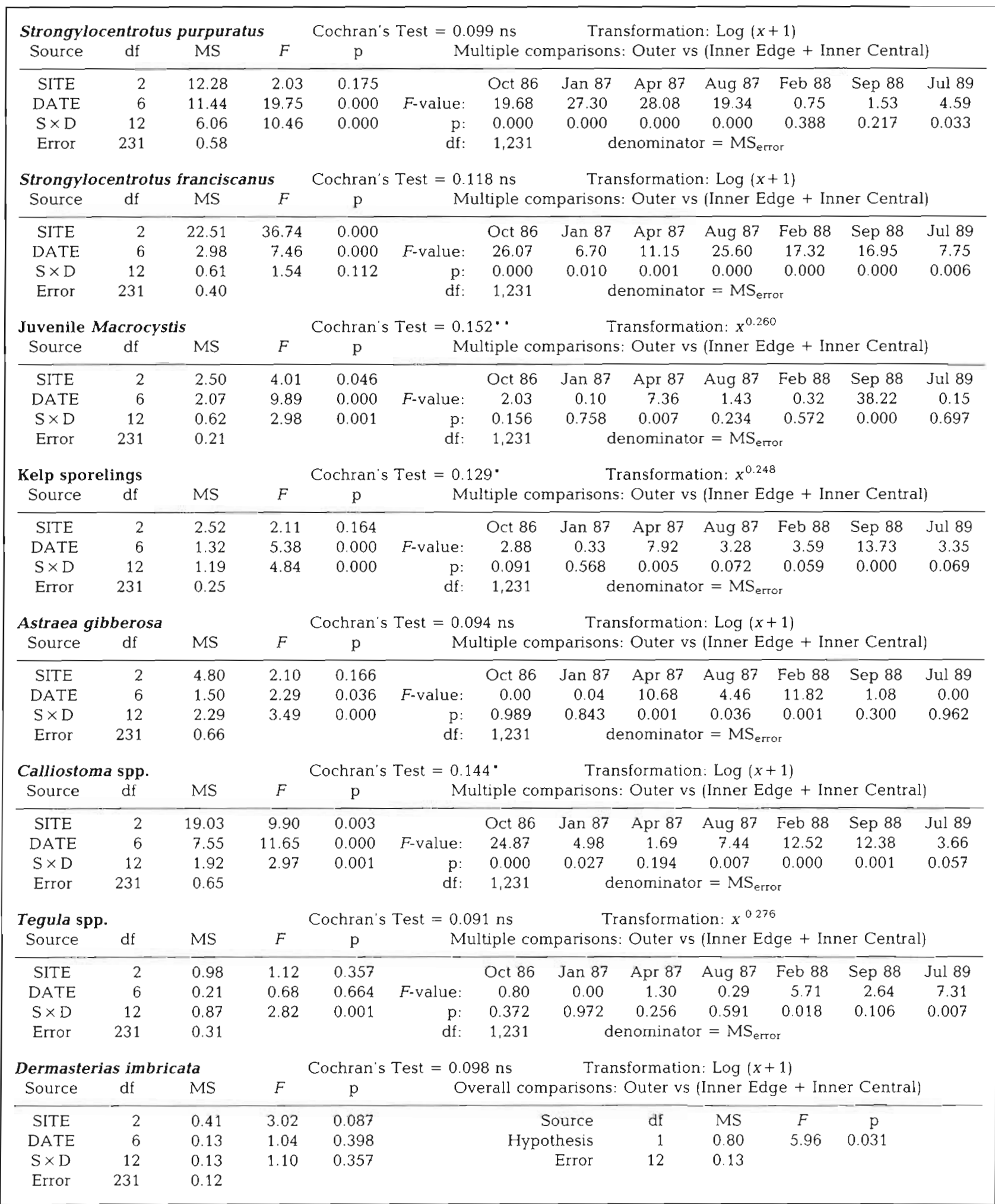


Table 3 (continued)

\begin{tabular}{|c|c|c|c|c|c|c|c|c|c|c|c|c|}
\hline \multicolumn{4}{|c|}{ Pisaster giganteus } & \multicolumn{9}{|c|}{ Cochran's Test $=0.190^{\cdots} \quad$ Transformation: $x^{0424}$} \\
\hline Source & df & MS & $F$ & $\mathrm{p}$ & \multicolumn{8}{|c|}{ Multiple comparisons: Outer vs (Inner Edge + Inner Central) } \\
\hline SITE & 2 & 0.16 & 0.85 & 0.451 & & Oct 86 & Jan 87 & Apr 87 & Aug 87 & Feb 88 & Sep 88 & Jul 89 \\
\hline DATE & 6 & 0.26 & 1.90 & 0.083 & $F$-value: & 0.04 & 0.00 & 1.93 & 2.92 & 0.92 & 0.10 & 0.36 \\
\hline $\mathrm{S} \times \mathrm{D}$ & 12 & 0.18 & 1.36 & 0.189 & p: & 0.833 & 1.00 & 0.166 & 0.089 & 0.338 & 0.749 & 0.550 \\
\hline Error & 231 & 0.14 & & & df: & 1.231 & & nominate & $\mathrm{r}=\mathrm{MS}_{\mathrm{er}}$ & & & \\
\hline \multicolumn{4}{|c|}{ Asterina (patiria) miniata } & \multicolumn{3}{|c|}{ Cochran's Test $=0.101 \mathrm{~ns}$} & \multicolumn{4}{|c|}{ Transformation: $\log (x+1)$} & & \\
\hline Source & $\mathrm{df}$ & MS & $F$ & $\mathrm{p}$ & & erall con & parisons: & Outer vs & (Inner Ec & $g e+\operatorname{In} r$ & ier Centra & \\
\hline SITE & 2 & 2.20 & 4.84 & 0.029 & & & Source & $\mathrm{df}$ & MS & $F$ & $\mathrm{p}$ & \\
\hline DATE & 6 & 0.85 & 2.08 & 0.056 & & Hyp & thesis & 1 & 4.31 & 9.46 & 0.010 & \\
\hline$S \times D$ & 12 & 0.46 & 1.11 & 0.350 & & & Error & 12 & 0.46 & & & \\
\hline Error & 231 & 0.41 & & & & & & & & & & \\
\hline
\end{tabular}

\section{Sea urchin populations}

In August 1986, abundance of the purple sea urchin Strongylocentrotus purpuratus at the Outer Pinnacles was greater than $16 \mathrm{~m}^{-2}$ (Fig. 3) and remained significantly greater than the Inner Pinnacles through August 1987 (Table 3). Between August 1987 and February 1988 , abundance of $S$. purpuratus declined by ca $70 \%$. By July 1989 no $S$. purpuratus could be found at the Outer Pinnacles. A similar decline occurred at the Inner Pinnacles Edge site, although it was not nearly as drastic (Fig.3). Abundances at the Inner Pinnacles Central site rose to a peak in February 1988 and then declined (Fig. 3).

The red sea urchin Strongylocentrotus franciscanus was significantly more abundant at the Outer Pinnacles on all dates except January 1987 (Table 3). Although $S$. franciscanus also decreased during the 3 yr study, its initial densities were lower and its decline was not nearly as great as $S$. purpuratus (Fig. 3). Throughout the study, individual sea urchins of both species could always be found in open, unprotected microhabitats at the Outer Pinnacles.

Size distributions of Strongylocentrotus purpuratus at the Outer Pinnacles were unimodal around $30 \mathrm{~mm}$ (test diameter) and did not shift markedly through time. Few large $(>60 \mathrm{~mm}$ ) or small $(<10 \mathrm{~mm})$ individuals were present (Fig. 4). Since the Outer Pinnacles had practically no algal or invertebrate cover, small urchins would have been easy to find had they been present.
Fig. 4. Strongylocentrotus purpuratus. Size-frequency distributions at the Outer and Inner Pinnacles

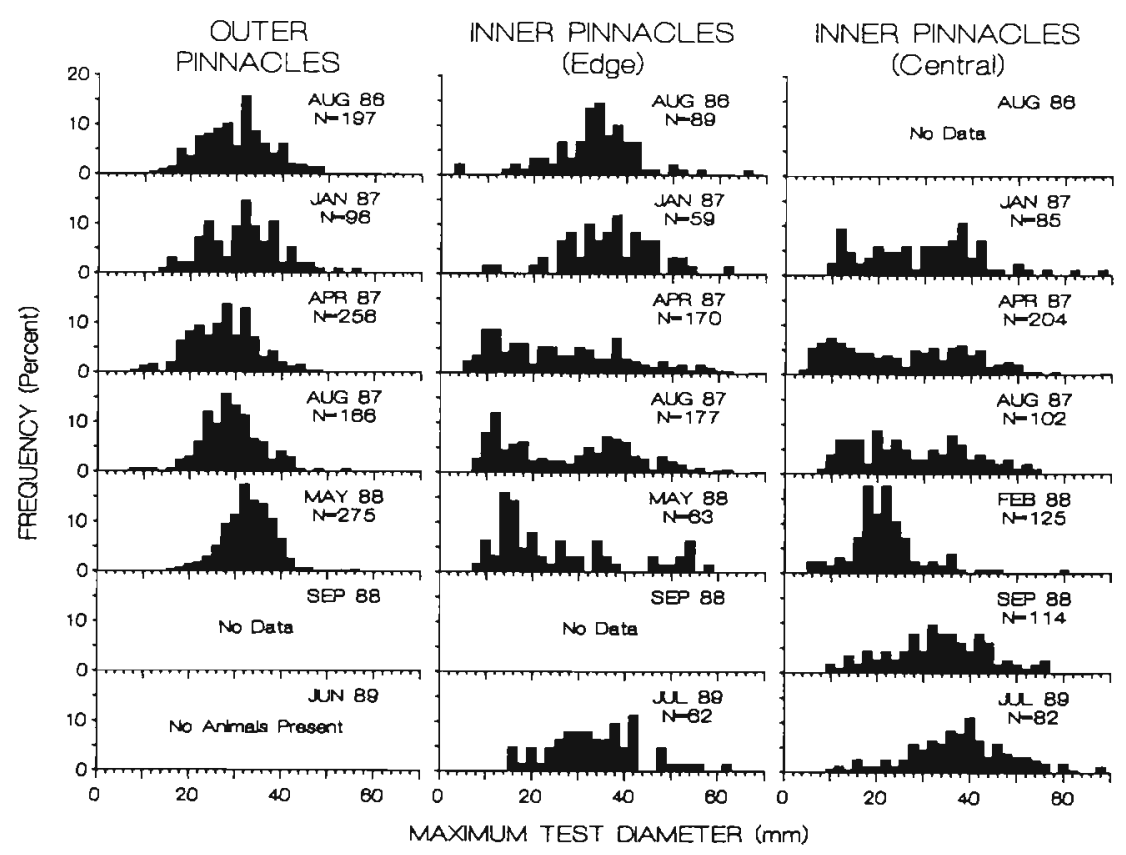




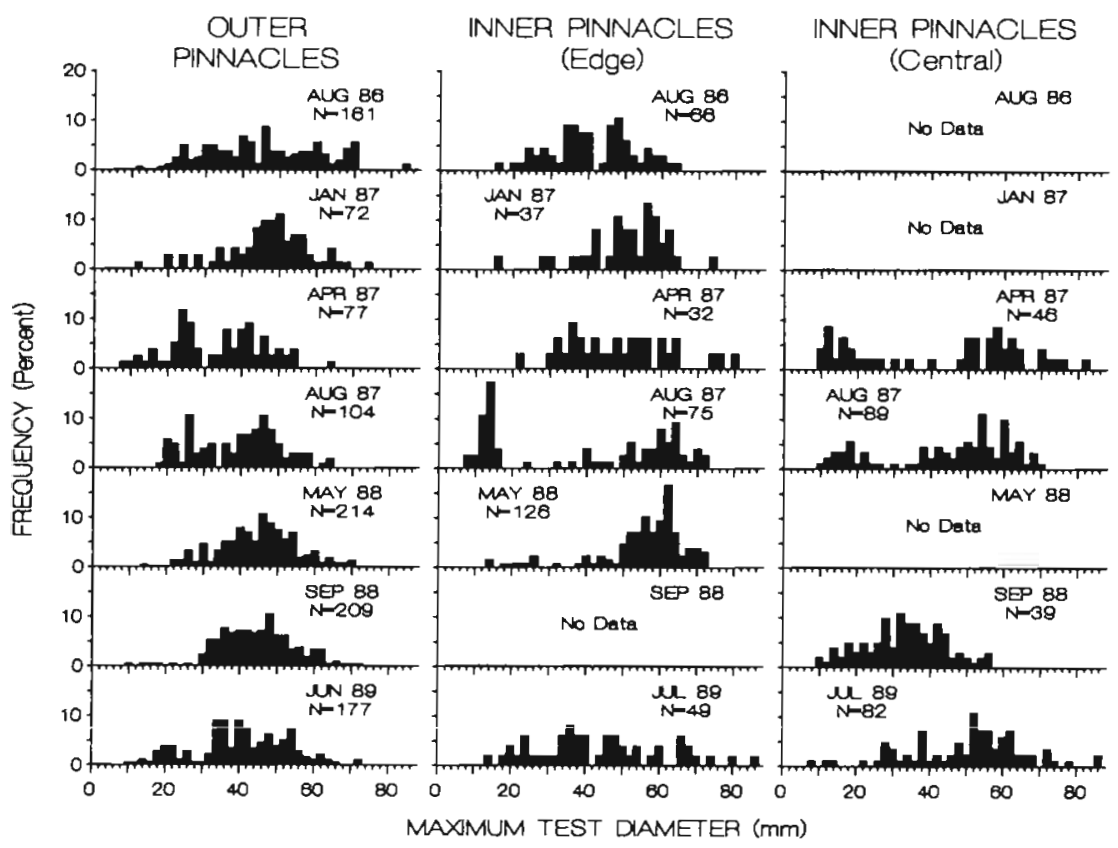

Fig. 5. Strongylocentrotus franciscanus. Size-frequency distributions at the Outer and Inner Pinnacles

Size distributions of $S$. purpuratus at the Inner Edge and Central sites were more variable (Fig. 4). Unlike the Outer Pinnacles, peaks at small sizes occurred on several occasions (January 1987 through May 1988), indicating potential recruitment. When abundance peaked at the Inner Central site (February 1988), modal size was ca $20 \mathrm{~mm}$ (Figs. 3 \& 4).

Size distributions of Strongylocentrotus franciscanus were more similar among sites than those of $S$. pur- puratus, although small sample sizes from the Inner Pinnacles sites makes interpretation difficult (Fig.5). Individuals in excess of $60 \mathrm{~mm}$ were always present at all 3 sites.

Except for August 1986, gonad development of both species was significantly lower at the Outer Pinnacles compared to the mean of the Inner Pinnacles sites (Table 4, Fig.6). In addition to lower reproductive development, the guts of individuals collected at the

Table 4. One-way ANOVA of gonad index data (arcsine-transformed). Critical p-values $=0.05$ except where variances were heterogeneous (F-test for August 1986; Cochran's test for all other dates), in which case tests were carried out at the 0.01 level. For Cochran's Test, $\cdot \mathrm{p}<0.05 \cdots \mathrm{p}<0.01$, ns: not significant. Only the Outer site and the Inner Edge site were sampled in August 1986. For all other dates, 'Outer vs Inner' refers to multiple comparison between the Outer site and the mean of the 2 Inner sites

\begin{tabular}{|c|c|c|c|c|c|c|c|c|c|}
\hline \multicolumn{5}{|c|}{ Strongylocentrotus purpuratus } & \multicolumn{5}{|c|}{ Strongylocentrotus franciscanus } \\
\hline August 1986: & & $F$-test $=2.5$ & & & August 1986: & & $F$-test $=2.8$ & & \\
\hline Source & $\mathrm{df}$ & MS & $F$ & $\mathrm{p}$ & Source & df & MS & $F$ & $\mathrm{p}$ \\
\hline$\overline{\text { SITE }}$ & $\overline{1}$ & 35.02 & 1.03 & $0 . \overline{315}$ & SITE & 1 & $5 \overline{9.44}$ & $1 . \overline{10}$ & 0.298 \\
\hline ERROR & 50 & 34.07 & & & ERROR & 57 & 53.81 & & \\
\hline February 1988: & & Cochran's & st $=0$. & ns & February 1988: & & Cochran's & est $=0$ & $\cdots$ \\
\hline Source & $\mathrm{df}$ & MS & $F$ & $p$ & Source & $\mathrm{df}$ & MS & $F$ & $\mathrm{p}$ \\
\hline SITE & 2 & 449.30 & 20.27 & 0.000 & SITE & 2 & $\overline{781.81}$ & 18.03 & 0.000 \\
\hline Outer vs Inner & 1 & 128.59 & 5.80 & 0.020 & Outer vs Inner & 1 & 1073.02 & 24.74 & 0.000 \\
\hline ERROR & 43 & 22.17 & & & ERROR & 40 & 43.47 & & \\
\hline September 1988: & & Cochran's & st $=0$. & & September 1988: & & Cochran's & st $=0$. & ns \\
\hline Source & $\mathrm{df}$ & MS & $F$ & $p$ & Source & $\mathrm{df}$ & MS & $F$ & $\mathrm{p}$ \\
\hline$\overline{\text { SITE }}$ & 2 & 1233.19 & 15.79 & 0.000 & SITE & 2 & 1876.56 & 49.91 & 0.000 \\
\hline Outer vs Inner & 1 & 2080.94 & 26.65 & 0.000 & Outer vs Inner & 1 & 3732.95 & 97.30 & 0.000 \\
\hline ERROR & 39 & 78.08 & & & ERROR & 48 & 38.36 & & \\
\hline \multirow{5}{*}{\multicolumn{5}{|c|}{$\begin{array}{c}\text { June 1989: No individuals present at } \\
\text { Outer Pinnacles site }\end{array}$}} & June 1989: & \multicolumn{4}{|c|}{ Cochran's Test $=0.479 \mathrm{~ns}$} \\
\hline & & & & & Source & $\mathrm{df}$ & MS & $F$ & $\mathrm{p}$ \\
\hline & & & & & SITE & 2 & 800.89 & $19 . \overline{53}$ & $\overline{0.000}$ \\
\hline & & & & & Outer vs Inner & 1 & 1486.11 & 36.25 & 0.000 \\
\hline & & & & & ERROR & 42 & 41.00 & & \\
\hline
\end{tabular}




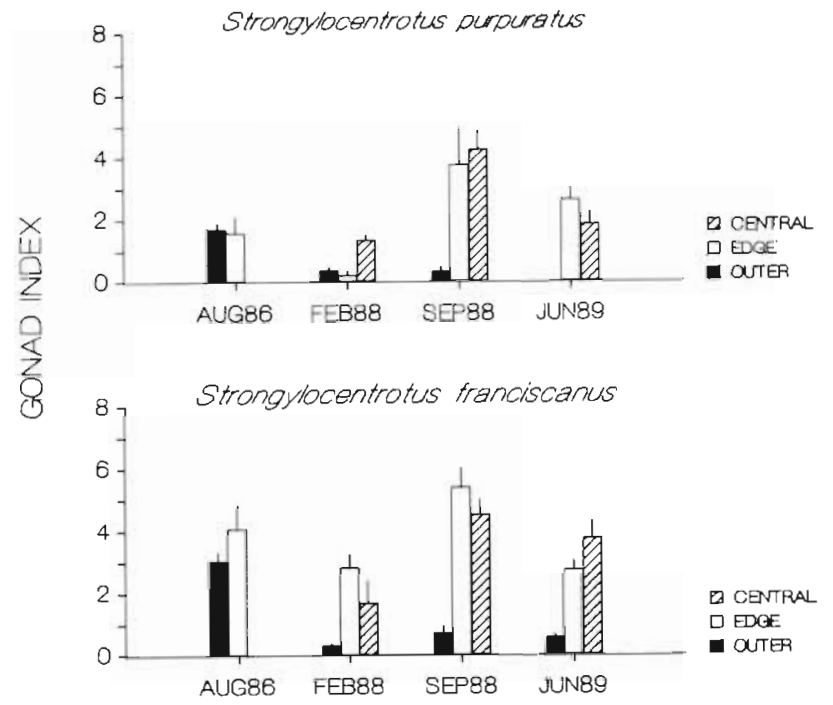

Fig. 6. Strongylocentrotus spp. Gonad index comparisons. The Inner Central site was not sampled in August 1986. No $S$. purpuratus were present at the Outer Pinnacles in June 1989 Error bars are one standard error of the mean

Outer Pinnacles were usually empty, while those from individuals collected at the Inner Pinnacles sites often contained red or brown algae.

\section{Other mobile invertebrates}

The gastropod Astraea gibberosa increased to a peak of $>8 \mathrm{~m}^{-2}$ at the Outer Pinnacles in February 1988 (Fig. 7). Greater numbers were found at Outer Pinnacles than Inner Pinnacles in April 1987 and February 1988 (Table 3). On several occasions individual quadrats with more than 20 snails $\mathrm{m}^{-2}$ were sampled at the Outer Pinnacles. Such high densities were not found in either of the Inner Pinnacles sites.

In October 1986 and February 1988, the abundance of top snails Calliostoma spp. (mostly C. ligatum and C. annulatum) was significantly greater at the Inner Pinnacles (Table 3). Abundances of turban snails Tegula spp. (mostly $T$. brunnea and $T$. pulligo) between the Outer Pinnacles and Inner Pinnacles were not significantly different on any date (Fig. 7, Table 3).

Of the 4 asteroid species that were sampled, 3 were sufficiently abundant to analyze. The leather star Dermasterias imbricata was more abundant at the Outer Pinnacles (Fig. 8, Table 3). Pisaster giganteus showed no significant differences among sites or dates (Fig. 8 , Table 3). The bat star Asterina (Patiria) miniata, the most common sea star in central California kelp forests, was significantly less abundant at the Outer Pinnacles during the study (Fig. 8, Table 3). Although it was observed in our sites on most sampling dates, the 20armed sea star Pycnopodia helianthoides occurred too rarely in the $1 \mathrm{~m}^{2}$ quadrats to analyze statistically. It occurred in at least one quadrat on only 1,0 , and 4 of 8 dates, respectively, for the Outer Pinnacles, Inner Pinnacles Edge, and Inner Pinnacles Central sites.

\section{Benthic community structure}

The number of sessile invertebrate taxa encountered at least once in the point-contact quadrats at the Outer Pinnacles decreased from 25 in August 1986 to 7 or 8 throughout the remainder of the study. Corresponding numbers for Inner Pinnacles Central were 21 to 26 and 15 to 23 for Inner Pinnacles Edge (Fig. 9).

The number of algal taxa encountered in the pointcontact quadrats at the Outer Pinnacles declined to a low of 2 in April 1987 (both were crustose taxa), then rose gradually to 10 by July 1989 (Fig. 9). The increase in number of taxa between early 1988 and the last census coincided with the decline in abundance of Strongylocentrotus purpuratus at this site. The number of algal taxa at the Inner Pinnacles Edge and Central sites was always greater than the Outer Pinnacles and remained more constant throughout the study (Fig. 9).
Fig. 7. Densities of 3 species of gastropods. Error bars are \pm one standard error of the mean
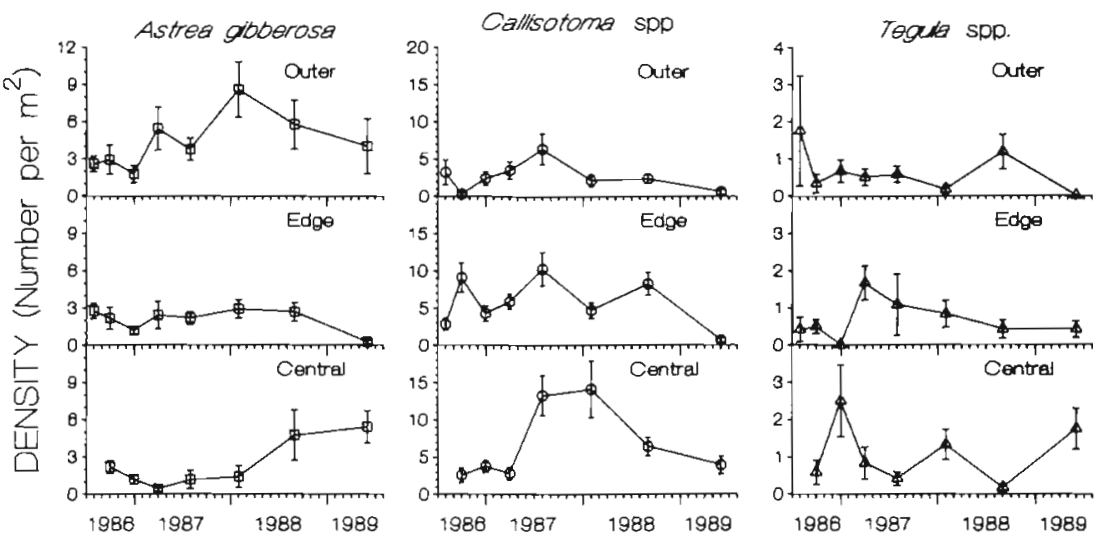

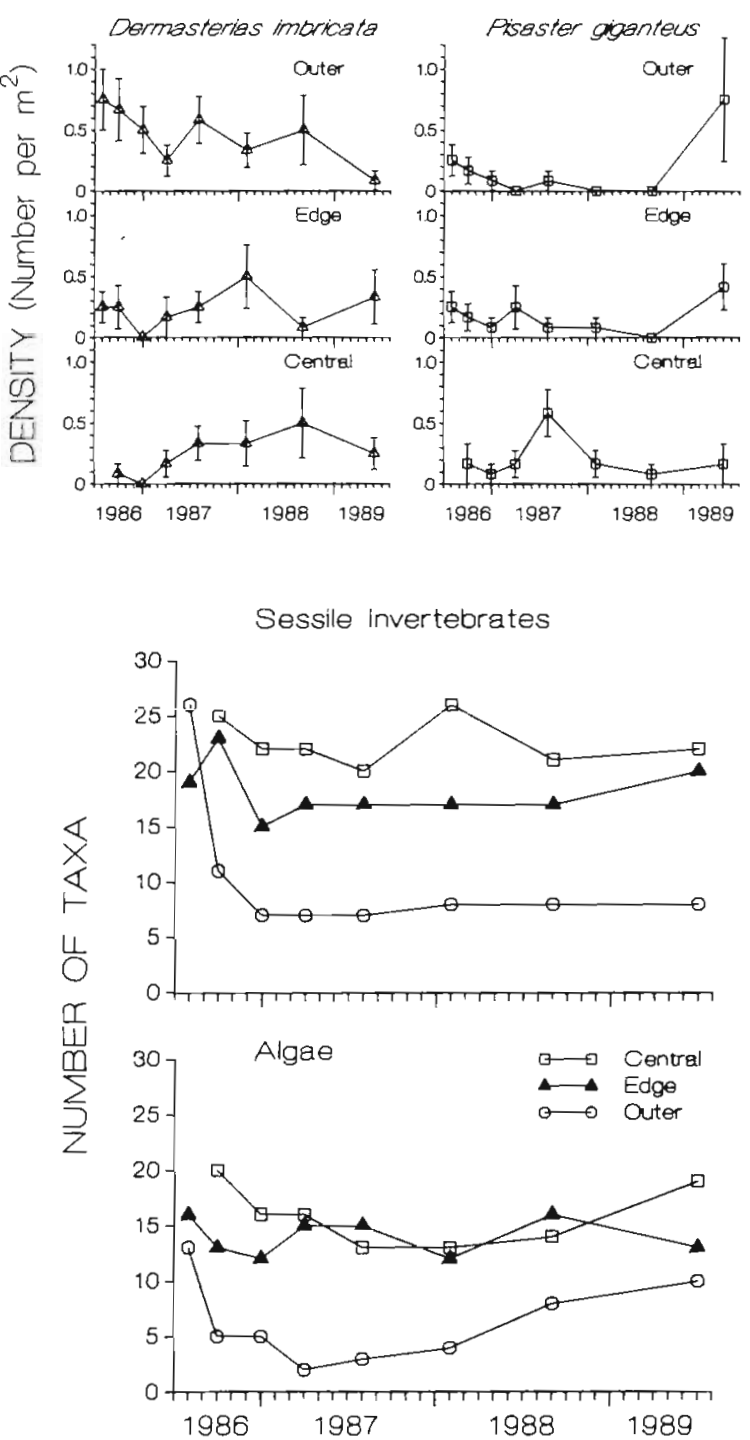

Fig. 9. Community structure. Number of taxa of sessile invertebrates and algae encountered in the point-contact quadrats on each sampling date

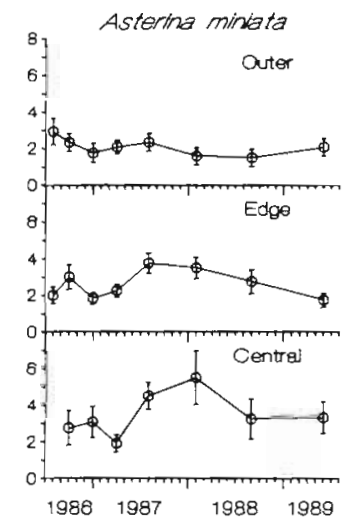

Fig. 8. Densities of 3 species of sea stars Error bars are \pm one standard error of the mean

\section{Benthic algae}

Adult Macrocystis pyrifera were absent from the Outer Pinnacles site throughout the study and only during the final census in July 1989 were any young sporelings or juvenile $M$. pyrifera encountered (Fig. 10). In contrast, adult $M$. pyrifera were always present at the 2 Inner Pinnacles sites (Fig. 2), as were variable numbers of juveniles and sporelings (Fig. 10). Peaks in abundance of both juvenile $M$. pyrifera and sporelings accurred at one or both Inner Pinnacles sites in April 1987 and September 1988; corresponding peaks were absent from the Outer Pinnacles. Differences between the Outer Pinnacles and the 2 Inner Pinnacles sites for both groups were significant in September 1988 (Table 3).

Stipitate understory kelp (Eisenia arborea, Laminaria setchellii, and Pterygophora californica) were absent from the Outer Pinnacles after August 1986 (Fig. 10). In August 1986, large ( $>1 \mathrm{~m}$ tall) stipitate kelps were found lying on the bottom at Outer Pinnacles with grazing scars around the stipe bases. Large numbers of sea urchins were present on the fronds. The lower portions of the few plants still standing were covered
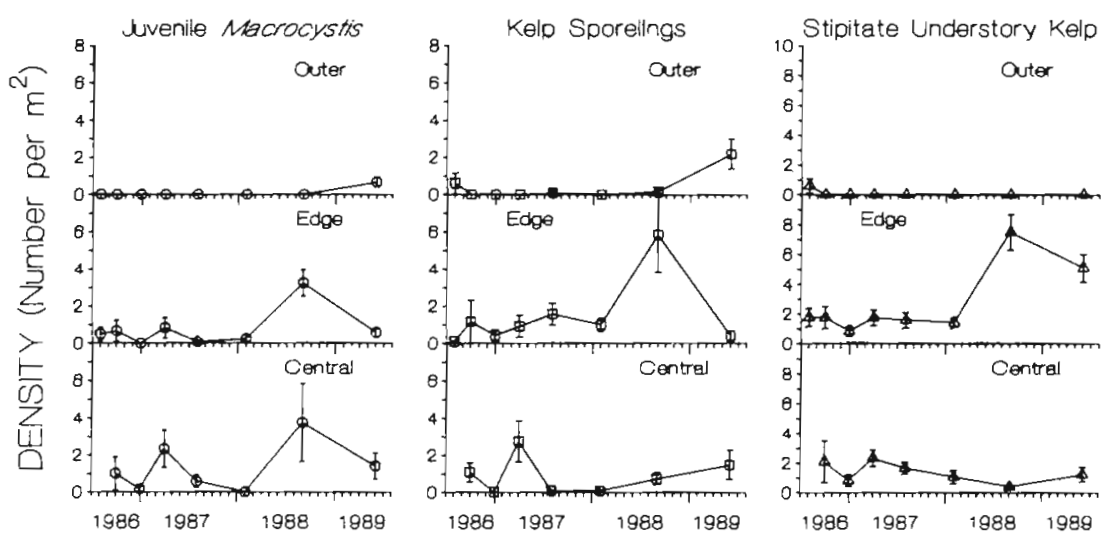

Fig. 10. Densities of juvenile Macrocystis pyrifera, kelp sporelings, and stipitate understory kelps. Error bars are \pm one standard error of the mean 
with sea urchins. Since storms of sufficient magnitude to break these plants had not occurred for at least several months before our first sample, their destruction was probably the direct result of sea urchin grazing.

Recruitment of stipitate understory kelp occurred at the Inner Edge site between February and September 1988 (Fig. 10). These data were not analyzed statistically because counts (and variances) for all dates (excluding August 1986) were zero at Outer Pinnacles.

Fleshy (non-coralline) red algae (Table 2) were absent from the Outer Pinnacles after August 1986 and reappeared only after the decline of Strongylocentrotus purpuratus (Fig. 11). In contrast, fleshy red algae were always present at the Inner Pinnacles, although abundances were highly variable among dates. Except for January 1987 and July 1989, percent cover of fleshy red algae was always significantly lower at the Outer Pinnacles (Table 5).

Algal species generally thought to be more resistant to sea urchin grazing, such as geniculate (articulated) corallines (Table 2) and the acid kelp Desmarestia ligulata var. firma and var. ligulata, also tended to be less abundant at the Outer Pinnacles (Fig. 11, Table 5). Geniculate corallines were significantly less abundant at the Outer Pinnacles (Table 5). No significant differences between sites were found for Desmarestia (Fig. 11, Table 5). However, as with fleshy red algae, this species reappeared at the Outer Pinnacles only after the abundance of $S$. purpuratus had declined (Fig. 11).

The absence of canopy and understory kelp from the Outer Pinnacles was not due to a lack of spores. All recruitment samplers were colonized by both red and brown seaweeds. Most of the small brown blades were Macrocystis, although identifiable individuals of other brown algae also were encountered. Recruitment was significantly greater at the Outer Pinnacles (Table 6). Shorter deployment duration may have caused low abundance of recruits at the Inner Central site. However, even if levels there were comparable to the Inner Edge site, recruitment would still have been at least as high at the Outer Pinnacles. Thus, grazing at the Outer Pinnacles, rather than lack of algal spores, was probably largely responsible for the continued absence of macroalgae.

\section{Sessile invertebrates}

Compound ascidians were significantly less abundant at the Outer Pinnacles from October 1986 through August 1987 (Fig. 12, Table 5). Between September 1988 and July 1989, after abundance of Strongylocentrotus purpuratus had declined, cover of ascidians increased at the Outer Pinnacles (mostly Didemnum carnulentum; Fig. 12). The concurrent increase in percent cover of ascidians at the Inner Edge site was due to recruitment of Aplidium californicum.

Erect bryozoans (Table 2) were absent from quadrats sampled at the Outer Pinnacles except in August 1986 and February 1988 (Fig. 12, Table 5). The patchy distribution of sponges at the Inner Pinnacles resulted in large within-site variances for most dates (Fig. 12). Despite this, abundance at the Outer Pinnacles was significantly lower than the Inner Pinnacles (Table 5).

In contrast to the above species, nongeniculate (encrusting) coralline algae (Table 2) and the cnidarians Corynactis californica and Balanophyllia elegans showed either no differences among sites or were actually more abundant at the Outer Pinnacles (Fig. 13, Table 5). Nongeniculate corallines increased to $>80 \%$ cover at the Outer Pinnacles, but declined to ca $50 \%$ by July 1989 as other erect species began to recolonize. For $C$. californica, overall differences among both sites and dates were not significant (Table 5). Abundance of $B$. elegans varied significantly among dates, but not among sites (Fig. 13, Table 5).
Fig. 11. Percent cover of fleshy (noncoralline) red algae, geniculate (articulated) coralline algae, and Desmarestia ligulata (var. ligulata and firma). See Table 2 for individual species included in the first 2 categories. Error bars are \pm one standard error of the mean
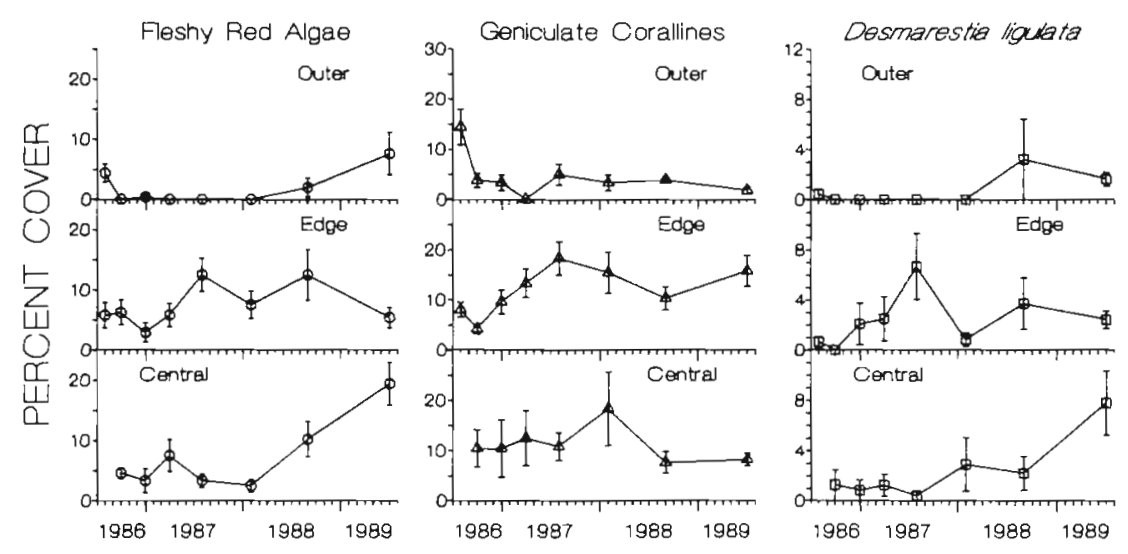
Table 5. Two-way ANOVA of percent cover data (SITE fixed, DATE random; arcsine-transformed). Where variances were heterogeneous, critical $p$-values $=0.01$; otherwise 0.05 . When site-by-date interactions were significant $(p<0.20)$, multiple comparisons were made for each date separately; critical p-values for individual dates were adjusted to $0.007(0.001$ if variances were heterogeneous; see 'Materials and methods'). For Cochran's Test, $p<0.05, \cdots p<0.01$, ns: not significant

\begin{tabular}{|c|c|c|c|c|c|c|c|c|c|c|c|c|}
\hline \multicolumn{5}{|c|}{ Fleshy red algae } & \multirow{2}{*}{\multicolumn{8}{|c|}{$\begin{array}{l}\text { Cochran's Test }=0.105 \mathrm{~ns} \\
\quad \text { Multiple comparisons: Outer vs (Inner Edge + Inner Central) }\end{array}$}} \\
\hline \multirow{2}{*}{$\frac{\text { Source }}{\text { SITE }}$} & \multirow{2}{*}{$\frac{\mathrm{df}}{2}$} & \multirow{2}{*}{$\frac{\text { MS }}{9278.39}$} & \multirow{2}{*}{$\frac{F}{12.31}$} & \multirow{2}{*}{$\frac{p}{0.001}$} & & & & & & & & \\
\hline & & & & & \multirow[b]{2}{*}{ F-value: } & \multirow{4}{*}{$\begin{array}{c}\text { Oct } 86 \\
11.42 \\
0.001 \\
1,189\end{array}$} & \multirow{3}{*}{$\begin{array}{c}\operatorname{Jan} 87 \\
2.02 \\
0.157\end{array}$} & \multirow{3}{*}{$\begin{array}{l}\text { Apr } 87 \\
12.75 \\
0.000\end{array}$} & \multirow{3}{*}{$\begin{array}{l}\text { Aug } 87 \\
16.54 \\
0.000\end{array}$} & \multirow{3}{*}{$\begin{array}{c}\text { Feb } 88 \\
7.65 \\
0.006\end{array}$} & \multirow{3}{*}{$\begin{array}{l}\text { Sep } 88 \\
19.25 \\
0.000\end{array}$} & \multirow{2}{*}{$\begin{array}{r}\text { Jul } 89 \\
3.69\end{array}$} \\
\hline DATE & 6 & 1945.36 & 6.95 & 0.000 & & & & & & & & \\
\hline $\mathrm{S} \times \mathrm{D}$ & 12 & 753.72 & 2.69 & 0.002 & p: & & & & & & & 0.056 \\
\hline Error & 189 & 279.93 & & & df: & & & nominatc & or $=\mathrm{MS}_{\mathrm{err}}$ & & & \\
\hline \multicolumn{5}{|c|}{ Geniculate (articulated) coralline algae } & Cochran & s Test $=$ & $0.185^{*}$ & & & & & \\
\hline Source & $\mathrm{df}$ & MS & $F$ & $\mathrm{p}$ & & verall cor & nparison: & Outer vs & (Inner Edg & $g e+\operatorname{Inn}$ & er Central) & \\
\hline SITE & 2 & 10106.82 & 20.53 & 0.000 & & & Source & $\mathrm{df}$ & MS & $F$ & $\bar{p}$ & \\
\hline DATE & 6 & 546.87 & 1.21 & 0.304 & & Hyp & thesis & 1 & 19345.27 & 39.29 & 0.000 & \\
\hline $\mathrm{S} \times \mathrm{D}$ & 12 & 492.34 & 1.09 & 0.373 & & & Error & 12 & 492.34 & & & \\
\hline Error & 189 & 452.69 & & & & & & & & & & \\
\hline Desmare & spp. & & & & Cochran & s Test $=$ & $.145^{\circ}$ & & & & & \\
\hline Source & $\mathrm{df}$ & MS & $F$ & $\mathrm{p}$ & & Itiple cor & nparisons & Outer vs & s (Inner Ed & $\operatorname{dge}+\operatorname{Inr}$ & er Centra & \\
\hline SITE & 2 & 1090.31 & 3.96 & 0.048 & & Oct 86 & $\operatorname{Jan} 87$ & Apr 87 & Aug 87 & Feb 88 & Sep 88 & Jul 89 \\
\hline$D A T E$ & 6 & 823.44 & 4.54 & 0.000 & $F$-value: & 0.15 & 1.02 & 1.77 & 4.92 & 1.67 & 0.83 & 3.81 \\
\hline$S \times D$ & 12 & 275.43 & 1.52 & 0.120 & $\mathrm{p}:$ & 0.692 & 0.314 & 0.185 & 0.028 & 0.197 & 0.365 & 0.052 \\
\hline Error & 189 & 181.28 & & & $\mathrm{df}:$ & 1,189 & do & nominato & or $=\mathrm{MS}_{\mathrm{err}}$ & & & \\
\hline Compour & ascidi & ans & & & Cochran & Test $=$ & $.113 \mathrm{~ns}$ & & & & & \\
\hline Source & $\mathrm{df}$ & MS & $F$ & $\mathrm{p}$ & $\mathrm{M}$ & litiple cor & nparisons & Outer vs & s (Inner Ed & Ige + Inn & er Centra & \\
\hline$\overline{\text { SITE }}$ & 2 & 10015.58 & 17.83 & 0.000 & & Oct 86 & $\operatorname{Jan} 87$ & Apr 87 & Aug 87 & Feb 88 & Sep 88 & Jul 89 \\
\hline DATE & 6 & 949.96 & 2.38 & 0.031 & F-value: & 14.08 & 16.20 & 9.84 & 14.74 & 1.82 & 1.80 & 0.001 \\
\hline$S \times D$ & 12 & 561.85 & 1.41 & 0.165 & $\mathrm{p}$ & 0.000 & 0.000 & 0.002 & 0.000 & 0.179 & 0.182 & 0.981 \\
\hline Error & 189 & 398.90 & & & $\mathrm{df}:$ & 1,189 & $d$ & nominato & $\mathrm{pr}=\mathrm{MS}_{\mathrm{errc}}$ & & & \\
\hline Erect bry & oans & & & & Cochran' & S Test $=$ & $.157^{\circ}$ & & & & & \\
\hline Source & $\mathrm{df}$ & MS & $F$ & $\mathrm{p}$ & & verall con & iparison: & Outer vs & (Inner Edg & ge + Inne & r Central) & \\
\hline SITE & 2 & 3568.11 & 17.45 & 0.000 & & & source & $\mathrm{df}$ & $\mathrm{MS}$ & $F$ & $\mathrm{p}$ & \\
\hline DATE & 6 & 212.17 & 1.10 & 0.365 & & Hyps & thesis & 1 & 6995.33 & 34.20 & 0.000 & \\
\hline$S \times D$ & 12 & 204.51 & 1.06 & 0.398 & & & Error & 12 & 204.51 & & & \\
\hline Error & 189 & 193.33 & & & & & & & & & & \\
\hline Sponges & & & & & Cochran' & Test $=0$ & $162 \cdots$ & & & & & \\
\hline Source & $\mathrm{df}$ & MS & $F$ & $p$ & & verall con & parison: & Outer vs & (Inner Edg & $\mathrm{ge}+\mathrm{Inne}$ & r Central) & \\
\hline SITE & 2 & 2805.25 & 9.09 & 0.004 & & & Source & $\mathrm{df}$ & MS & $\bar{F}$ & $\mathrm{p}$ & \\
\hline DATE & 6 & 165.40 & 0.69 & 0.661 & & Hypc & thesis & 1 & 5196.04 & 16.83 & 0.001 & \\
\hline$S \times D$ & 12 & 308.64 & 1.28 & 0.233 & & & Error & 12 & 308.64 & & & \\
\hline Error & 189 & 241.14 & & & & & & & & & & \\
\hline Nongenic & ate len & Icrusting) cc & oralline & lgae & Cochran' & Test $=0$ & $131 \mathrm{~ns}$ & & & & & \\
\hline Source & $\mathrm{df}$ & MS & $F$ & $\mathrm{p}$ & & erall con & parison: & Outer vs & (Inner Edg & $y e+$ Inne & r Central) & \\
\hline SITE & 2 & 15631.51 & 50.44 & 0.000 & & & ource & $\mathrm{df}$ & MS & $F$ & $\mathrm{p}$ & \\
\hline DATE & 6 & 4433.63 & 9.80 & 0.000 & & Hypo & thesis & 1 & 31207.63 & 100.72 & 0.000 & \\
\hline$S \times D$ & 12 & 309.90 & 0.68 & 0.765 & & & Error & 12 & 309.90 & & & \\
\hline Error & 189 & 452.51 & & & & & & & & & & \\
\hline Corynact & califor & nica & & & Cochran' & Test $=0$ & 105 ns & & & & & \\
\hline Source & $\mathrm{df}$ & MS & $F$ & $\mathrm{p}$ & & erall com & parison: & Duter vs & (Inner Edg & re + Inne & ( Central) & \\
\hline SITE & 2 & 305.24 & 0.67 & 0.530 & & & ource & $\mathrm{df}$ & MS & $F$ & $\mathrm{p}$ & \\
\hline DATE & 6 & 693.53 & 1.95 & 0.075 & & Hypo & thesis & 1 & 25.14 & 0.05 & 0.818 & \\
\hline$S \times D$ & 12 & 456.00 & 1.28 & 0.231 & & & Error & 12 & 456.00 & & & \\
\hline Error & 189 & 355.48 & & & & & & & & & & \\
\hline Balanoph & lia eles & gans & & & Cochran & Test $=0$ & $.122 \mathrm{~ns}$ & & & & & \\
\hline Source & $\mathrm{df}$ & MS & $F$ & $\mathrm{p}$ & & erall com & parison: & Duter vs & (Inner Edg & e + Inne & r Centra!) & \\
\hline SITE & 2 & 539.23 & 1.88 & 0.195 & & & ource & $\mathrm{df}$ & MS & $F$ & $\mathrm{p}$ & \\
\hline DATE & 6 & 1336.51 & 4.99 & 0.000 & & Hypo & thesis & 1 & 1073.91 & 3.74 & 0.077 & \\
\hline$S \times D$ & 12 & 287.43 & 1.07 & 0.385 & & & Error & 12 & 287.43 & & & \\
\hline Error & 189 & 267.84 & & & & & & & & & & \\
\hline
\end{tabular}




\section{DISCUSSION}

The well-developed kelp forest at the Outer Pinnacles disappeared in early 1986. While the proximate cause of the deforestation was a high abundance of sea urchins, factors responsible for its initiation are not clear.

The initial increase in sea urchin abundance probably occurred through larval settlement, rather than immigration. In central California, there are no large populations of sea urchins in deeper water adjacent to kelp forests that can provide a source of adult immigrants. This contrasts with the Aleutian Islands, where sea urchins are abundant below 16 to $18 \mathrm{~m}$, even where sea otters are present (Dayton 1975a, Estes et al. 1978). Near Pescadero Point (within $2 \mathrm{~km}$ of the Outer Pinnacles; Fig. 1), Kenner (1987) observed high recruitment of Strongylocentrotus purpuratus in early 1984, little or no recruitment in 1985, and light recruitment in 1986. By September 1986, the 1984 cohort had reached $30 \mathrm{~mm}$ test diameter, similar to the population mode at the Outer Pinnacles. S. purpuratus at the Outer Pinnacles probably belonged to this 1984 cohort.

A second factor related to initiation of the deforestation was probably food abundance. Abundance of drift algae can trigger changes in sea urchin feeding behavior, leading to either a deforested or kelp-dominated state without a change in overall sea urchin abundance (Ebeling et al. 1985, Harrold \& Reed 1985). Reduction of food at the Outer Pinnacles during winter 1986 may have caused such a switch in feeding behavior of the 1984 cohort, leading to deforestation.

Table 6. Mean number of recruits per meter of line after 6 mo (Inner Pinnacles Central) or 8 mo (Outer Pinnacles and Inner Pinnacles Edge). ANOVA conducted on log-transformed data $[\log (x+1)$; Cochran's Test on untransformed data $=0.883$, $\mathrm{p}<0.01$ ]. 'Outer vs Inner' is a multiple comparison of the Outer site compared to the mean of the 2 Inner sites. Two of the 5 samplers originally deployed at the Outer Pinnacles were not recovered

\begin{tabular}{|c|c|c|c|c|}
\hline Site & & Mean & SE & $\mathrm{n}$ \\
\hline Outer Pinnacles & & 206.8 & 6.91 & 3 \\
\hline Inner Edge & & 45.5 & 21.54 & 5 \\
\hline Inner Central & & 9.2 & 3.32 & 5 \\
\hline \multicolumn{5}{|c|}{ ANOVA: Cochran's Test $=0.383 \mathrm{~ns}$} \\
\hline Source & df & MS & F & $p$ \\
\hline SITE & 2 & 9.06 & 12.46 & 0.002 \\
\hline Outer vs Inner & 1 & 13.06 & 17.95 & 0.002 \\
\hline ERROR & 10 & 0.78 & & \\
\hline
\end{tabular}

Fig. 12. Percent cover of compound ascidians, erect bryozoans, and sponges. See Table 2 for individual species included in each category. Error bars are \pm one standard error of the mean

Fig. 13. Percent cover of nongeniculate (crustose) coralline algae, Corynactis californica, and Balanophyllia elegans. Error bars are \pm one standard error of the mean
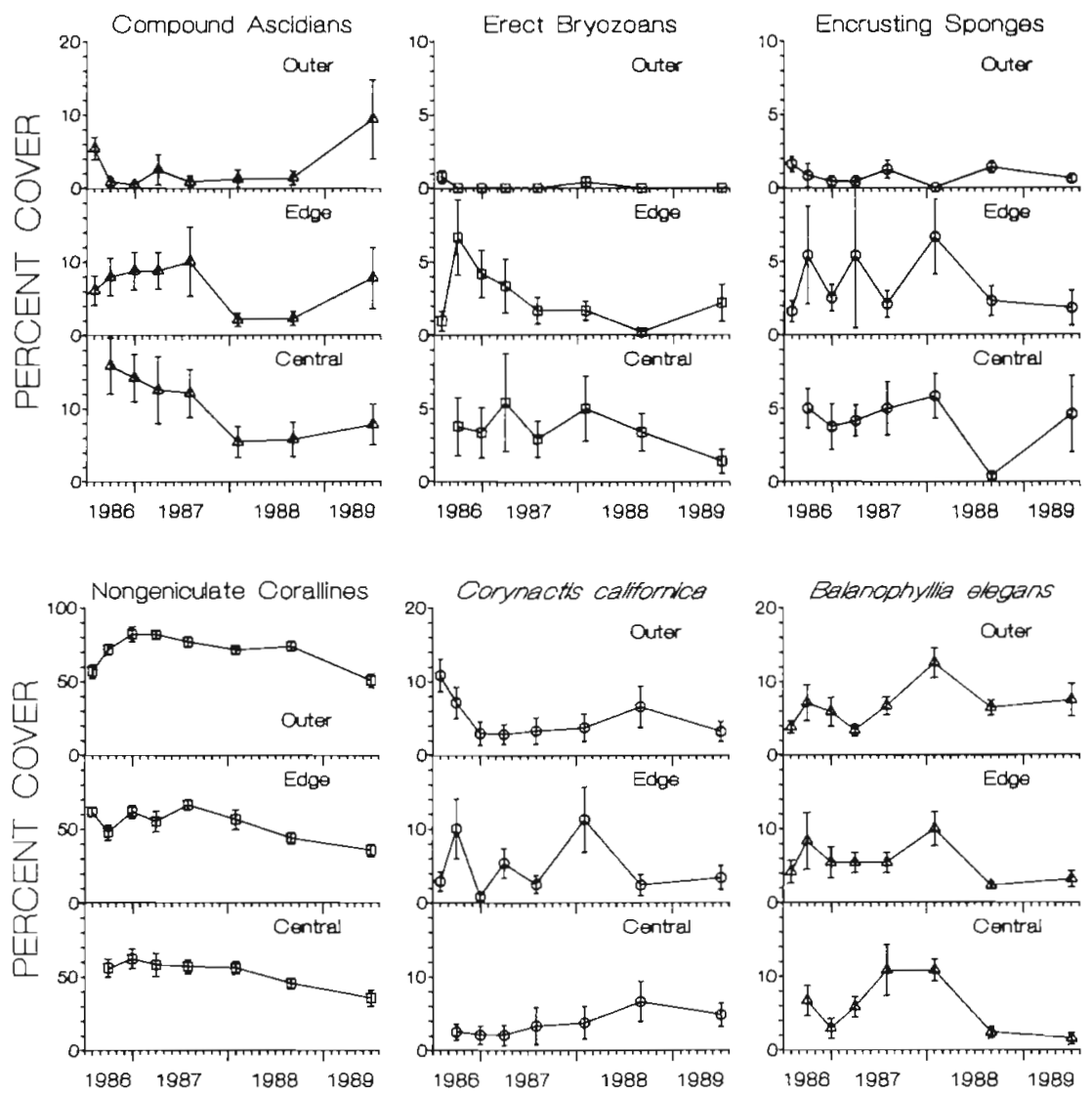
Despite a lack of pre-deforestation in situ data, it appears likely that high settlement of sea urchin larvae occurred in 1984, followed by good post-settlement survival. This large cohort subsisted and grew on unattached drift kelp until winter of 1986, when the combined effects of reduced food and high numbers of large sea urchins triggered active grazing on attached algae and subsequent deforestation.

Once active grazing commenced, erect seaweeds (canopy, stipitate understory, small benthic reds) declined and remained nearly absent from the Outer Pinnacles, even though spores were available for settlement. Sessile invertebrates also declined at the Outer Pinnacles. In August and October 1986, when patches of algal/invertebrate turf were still present at Outer Pinnacles, we observed sea urchins either ingesting or dislodging invertebrate colonies from the substrate. Sinulila negative effects of sea urchin grazing on sessile invertebrates have been observed in other locations (e.g. Ebert 1977, Vance 1979, Gerrodette 1981). As in previous studies of sea-urchin dominated areas (e.g. Estes \& Palmisano 1974, Breen \& Mann 1976. Harrold \& Reed 1985), nongeniculate (encrusting) coralline algae became the most prevalent taxa at the deforested site, and overall species diversity was low.

Neither the high abundance of sea urchins nor its decline appeared to affect other mobile invertebrates to a great degree. In eastern Canada, Scheibling \& Raymond (1990) did not detect any individual or numerical responses of other invertebrate grazers to a reduction of sea urchin abundance by disease. Some of the variation observed for densities of non-urchin invertebrates was due to our sampling design: for instance, uncommon species such as Pycnopodia helianthoides and Dermasterias imbricata (Fig. 8) are not sampled efficiently in quadrats as small as $1 \mathrm{~m}^{2}$. For other species, such as the sea star Pisaster giganteus or the gastropods Calliostoma and Tegula spp., that may aggregate around sources of food, differences in abundances may reflect chance occurrence of such aggregations in a few quadrats. We never noted large numbers of small individuals of any of the non-urchin invertebrates, suggesting that heavy recruitment did not occur during the course of our study

\section{Sea urchin population dynamics}

Population dynamics of the 2 sea urchin species differed markedly. At the Outer Pinnacles, the abundance of Strongylocentrotus purpuratus declined from ca $16 \mathrm{~m}^{-2}$ to zero within $2 \mathrm{yr}$, while $S$. franciscanus population remained fairly stable (Fig. 3). Based on size distributions, recruitment also may have differed, although the data are of low resolution (Figs. $4 \&$ 5). If recruitment did occur between 1986 and 1989, it was more frequent at the forested site (at least for $S$. purpuratus), in contrast to previous studies which have inferred higher rates of sea urchin recruitment to deforested areas (Tegner \& Dayton 1981, Rowley 1989).

Reasons for decline of the Strongylocentrotus purpuratus population are not clear. Sea urchins do not prosper in deforested areas, but neither do they simply die of starvation (Lang \& Mann 1976, Johnson \& Mann 1982, Himmelman 1986). Rowley (1989) inferred that post-settlement survival of juvenile sea urchins was actually higher in deforested areas than in nearby kelpdominated areas. Weakness from food deprivation still may have been a factor. Larger sea urchins capture drift algae more efficiently (Duggins 1981b, Himmelman 1986), possibly putting smaller $S$. purpuratus at a competitive disadvantage. Weakened $S$. purpuratus may have then been removed differentially by storm waves during winter 1987-88. Significant wave heights exceeded $2 \mathrm{~m}$ on 28 days during December 1987 and January 1988 (heights exceeded $3 \mathrm{~m}$ on 12 of these days and $4 \mathrm{~m}$ on 2 days) at an exposed site within $6 \mathrm{~km}$ of the Outer Pinnacles. This was the most days of large waves during these months since November 1987 (Watanabe \& Harrold unpubl.).

Disease has caused mass mortalities of sea urchins in both temperate (Pearse et al. 1977, Pearse \& Hines 1979, Miller \& Colodey 1983, Scheibling \& Stephenson 1984) and tropical habitats (Lessios et al. 1984). Die-off may have occurred at the Outer Pinnacles between sampling dates, though we never observed or collected any diseased sea urchins. Previous outbreaks of sea urchin disease along the California coast were not species-specific (Johnson 1971, Pearse et al. 1977. J. Pearse pers. comm.), so while disease may be responsible for the decline of Strongylocentrotus purpuratus, such species specificity would be novel.

Differential predation on the 2 sea urchin species is another possible explanation. Although predation by sea otters in central California and elsewhere is highly influential (Estes \& Palmisano 1974, Estes et al. 1978, Duggins 1980, Breen et al. 1982, VanBlaricom 1984, Estes \& Harrold 1988), it is unlikely that sea otters were responsible for the decline of Strongylocentrotus purpuratus on the Outer Pinnacles. The sea otter population of the Carmel Bay area did not change substantially during this period (R. Jameson, US Fish \& Wildlife Service unpubl.). Throughout the study, both species of sea urchins remained in open, exposed microhabitats, in contrast to their more typical use of crevices in shallower kelp forests (Lowry \& Pearse 1973, Tegner \& Dayton 1981, Harrold \& Reed 1985, Pearse \& Hines 1987). Both species would thus have been susceptible to sea otters. Since sea otters tend to consume larger 
size classes of prey (Estes \& Palmisano 1974, Estes et al. 1978, VanBlaricom 1988), it is unlikely that they would have removed all the smaller $S$. purpuratus while leaving the larger $S$. franciscanus virtually untouched, despite their apparent equal availability

Depth has probably always limited predation by sea otters at the Outer Pinnacles. Although sea otters can dive to depths in excess of 40 m (Riedman \& Estes 1988) and individual otters near Monterey have been observed foraging deeper than $30 \mathrm{~m}$ (C. Deutsch unpubl., M. Riedman pers. comm.), observations from the Aleutian Islands suggest that sea otters effectively control sea urchin populations at depths less than 18 to $20 \mathrm{~m}$ (Dayton 1975a, Estes et al. 1978). Although circumstantial, evidence from the Outer Pinnacles indicates that a similar depth limitation exists for control of sea urchin populations by sea otters in central California.

Predators other than sea otters may have played a role in the decline of Strongylocentrotus purpuratus. The leather star Dermasterias imbricata preys primarily on cnidarians (Mauzey et al. 1968, Annett \& Pierotti 1984), but it also consumes small $S$. purpuratus (Rosenthal \& Chess 1972). The 20-armed starfish Pycnopodia helianthoides is also an important predator on sea urchins (Mauzey et al. 1968, Feder 1980, Duggins 1983, Herrlinger 1983). Field and laboratory studies have shown that $S$. purpuratus is more susceptible to predation by $P$. helianthoides than $S$. franciscanus (Moitoza \& Phillips 1979, Duggins 1981b, 1983, Tegner $\&$ Dayton 1981). Although the effect of $P$. helianthoides would be consistent with the differential decline of the 2 sea urchins, it occurred too rarely in our quadrat samples to make conclusive statements.

Predatory fishes such as the wolf eel Anarrichthys ocellatus also may have played a role. Wolf eels are known to occur at both sites and would probably have a greater impact on smaller Strongylocentrotus purpuratus. However, wolf eels were rarely, if ever, observed during the course of our study.

\section{Kelp forest community dynamics}

A key to understanding the dynamics of deforestations is the regulation of sea urchin populations. Before the events described here, control of sea urchin populations in central California was generally attributed to intense predation on adult sea urchins (primarily by sea otters). The events in Carmel Bay indicate that control of sea urchins by sea otters in California is probably limited to depths shallower than 18 to $20 \mathrm{~m}$ as in Alaska (e.g. Dayton 1975a, Estes et al. 1978). The typical low abundance of sea urchins below these depths in central California is probably more strongly influenced by other factors.
The rarity of sea-urchin mediated deforestations along the central California coast corresponds with a high degree of inter-annual variability in sea urchin recruitment. Between 1972 and 1981, recruitment of Strongylocentrotus purpuratus occurred only once, and $S$. franciscanus did not recruit at all in a kelp forest in southern Monterey Bay [Pearse \& Hines (1987); see Ebert (1968), Dayton (1975b), and Ebert \& Russell (1988) for additional examples]. In contrast, regular annual recruitment of both $S$. purpuratus and $S$. franciscanus occurs in southern California (Tegner \& Dayton 1981), where deforestations occur periodically (e.g. Tegner \& Dayton 1981, Harrold \& Reed 1985). Recruitment of Strongylocentrotus polyacanthus to chronically deforested areas in the Aleutian Islands also appears to be regular (unpubl. data cited in Estes \& VanBlaricom 1988). Because sea urchins must be sufficiently abundant to initiate a deforestation, infrequent recruitment in central California (followed by high attrition of juveniles) may maintain populations below that threshold most of the time.

In addition to potential limitation by recruitment, post-settlement mortality of young sea urchins also may be important in population regulation. Rowley (1989) and Harrold (unpubl.) found that larval settlement within a kelp forest was not always reflected by subsequent increases in juvenile sea urchin populations. Within $1 \mathrm{yr}$ of the single recruitment pulse observed by Pearse \& Hines (1987), most of the cohort had died, presumably from either disease or predation by sea stars. Sea otters are not responsible for mortality at these sizes, since they do not prey heavily on sea urchins smaller than 20 to $25 \mathrm{~mm}$ test diameter (Estes et al, 1978, Faurot et al. 1986).

In addition to adult mortality from predation or disease, potential regulation of sea urchin populations can occur at numerous points during their life history. Factors affecting the intensity and frequency of larval recruitment as well as those affecting early survival of juvenile sea urchins require further investigation. Biogeographic differences in predictability of recruitment may account for some of the variation in occurrence of deforestations world-wide.

The contrast between the Inner and Outer Pinnacles underscores the complex interactions that influence deforestations. Presumably both sites experienced strong sea urchin recruitment in 1984 (judging from abundances in 1986; Fig. 3) and both sites lost large proportions of their surface canopies in early 1986 (Fig. 2). However, despite similar depth ranges (and presumably similar low intensities of sea otter predation), the Outer Pinnacles became deforested, while the canopy at the Inner Pinnacles recovered and its sea urchin population declined sooner (Figs. 2 \& 3). Although many of the circumstances leading to initia- 
tion and recovery from deforestations are now clear, the interaction of these factors and the role of contingency in determining the intensity and diration of the outcome will provide fruitful areas for further research.

Acknowledgements. We gratefully acknowledge the assistance of numerous diving biologists from the Monterey Bay Aquarium, Hopkins Marine Station, Moss Landing Marine Laboratories and UC Santa Cruz; without their help this project would not have been possible. Students in the Biology $160 \mathrm{H}$ summer class at Hopkins Marine Station helped plan and carry out the initial sampling in August 1986. J. Ames of the California Department of Fish \& Game and G. R. VanBlaricom of US Fish \& Wildlife Service provided aerial canopy photos from the 1970 s and early 1980s. J. Graef assisted with analysis of surface canopy areas. R. Phillips analyzed the algal recruitment samplers. Special thanks to P. Barnett for assistance in the field and lab. We also acknowledge the faculty and staff of Hopkins Marine Station for use of their facilities. Financial and logistic support was provided by the Monterey Bay Aquarium. M. Foster, G. R. VanBlaricom, R. E. Phillips, and 2 anonymous reviewers provided comments on an earlier version of this manuscript. Contribution no. 18 from the Monterey Bay Aquarium.

\section{LITERATURE CITED}

Annett, C., Pierotti, R. (1984). Foraging behavior and prey selection of the leather sea star Dermasterias imbricata. Mar. Ecol. Prog. Ser. 14: 197-206

Breen, P. A., Mann, K. H. (1976). Destructive grazing of kelp by sea urchins in Eastern Canada. J. Fish. Res. Bd Can. 33: $1278-1283$

Breen, P. A., Carson, T. A., Foster, J. B., Steward, E. A. (1982). Changes in subtidal community structure associated with British Columbia sea otter transplants. Mar. Ecol. Prog. Ser. 7: $13-20$

Cowen, R. K., Agegian, C. R., Foster, M. S. (1982). The maintenance of community structure in a central California giānt kelp forest. J. exp. mar. Biol. Ecol. 64: 189-201

Dayton, P. K. (1975a). Experimental studies of algal canopy interactions in a sea otter dominated kelp community at Amchitka Island, Alaska. Fish. Bull. U.S. 73: 230-237

Dayton, P. K. (1975b). Experimental evaluation of ecological dominance in a rocky intertidal community. Ecol. Monogr. 45: $137-159$

Dayton, P. K. (1985). Ecology of kelp communities. A. Rev. Ecol. Syst., 16: 215-246

Duggins, D. O. (1980). Kelp beds and sea otters: an experimental aproach. Ecology 61: 447-453

Duggins, D. O. (1981a). Sea urchins and kelp: the effects of short term changes in urchin diet. Limnol. Oceanogr 26: 391-394

Duggins, D. O. (1981b). Interspecific facilitation in a guild of benthic marine herbivores. Oecologia (Berl.) 48: 157-163

Duggins, D. O. (1983). Starfish predation and creation of mosaic patterns in a kelp-dominated community. Ecology 64: 1610-1619

Ebeling, A. W., Laur, D. R., Rowley, R. J. (1985). Severe storm disturbances and reversal of community structure in a southern California kelp forest. Mar Biol. 84: 287-294

Ebert, T. A. (1968). Growth rates of the sea urchin Strongylocentrotus purpuratus related to food availability and spine abrasion. Ecology 49: 1075-1091
Ebert, T A. (1977). An experimental analysis of sea urchin dynamics and community interactions on a rocky jetty. $J$. exp. mar. Biol. Ecol. 27: 1-22

Ebert, T. A., Russell, M. P. (1988). Latitudinal variation in size structure of the west coast purple sea urchin: a correlation with headlands. Limnol. Oceanogr. 33: 286-294

Elliott, J. M. (1977). Some methods for the statistical analysis of samples of benthic invertebrates, 2nd edn. Freshwater Biol. Assoc. Sci. Publ. 25, 148 p

Estes, J. A., Harrold, C. (1988). Sea otters, sea urchins, and kelp beds: some questions of scale. In: VanBlaricom, G. R., Estes, J. A. (eds.) The community ecology of sea otters. Springer-Verlag, Berlin, p. 116-150

Estes, J. A., Palmisano. J. F. (1974). Sea otters: their role in structuring nearshore communities. Science 185: $1058-1060$

Estes, J. A., Smith, N. S., Palmisano, J. F. (1978). Sea otter predation and community organization in the Western Aleutian Is., Alaska. Ecology 59: 822-833

Estes, J. A., VanBlaricom, G. R. (1988). Concluding remarks In: VanBlaricom, G. R., Estes, J. A. (eds.) The community ecology uf sea otters. Springer-Verlag, Berilin, p. 210-213

Faurot, E. R., Ames, J. A., Costa, D. P. (1986). Analysis of sea otter, Enhydra Iutris, scats collected from a California haul out site. Mar. Mammal Sci. 2: 223-227

Feder, H. M. (1980). Asteroidea: the sea stars. In: Morris, R. H. Abbott, D. P., Haderlie, E. C. (eds.) Intertidal invertebrates of California. Stanford Univ. Press, Stanford, p. 117-135

Foster, M. S., Schiel, D. R. (1985). The ecology of giant kelp forests in California: a community profile. U.S. Fish Wildl Serv. Biol. Rep. 85 (7.2)

Foster, M. S., Schiel, D. R. (1988). Kelp communities and sea otters: keystone species or just another brick in the wall? In: VanBlaricom, G. R., Estes, J. A. (eds.) The community ecology of sea otters. Springer-Verlag, Berlin, p. 92-115

Gerrodette, T. (1981). Dispersal of the solitary coral Balanophyllia elegans by demersal planula larvae. Ecology 62 : 611-619

Harrold, C., Reed, D. C. (1985). Food availability, sea urchin grazing and kelp forest community structure. Ecology 66 $1160-1169$

Harrold, C., Pearse, J. S. (1987). The ecological role of echinoderms in kelp forests. In: Jangoux, M., Lawrence, J. M. (eds.) Echinoderm studies. Vol 2. A. A. Balkema, Rotterdam, p. 137-233

Herrlinger, T. J. (1983). The diet and predator-prey relation ships of the sea star Pycnopodia helianthoides (Brandt) from a central California kelp forest. MA thesis, Calif. State Univ. San Jose

Himmelman, J. H. (1986). Population biology of green sea urchins on rocky barrens. Mar. Ecol. Prog. Ser. 33: 295-306

Johnson, C. R., Mann, K. H. (1982). Adaptations of Strongylocentrotus droebachiensis for survival on barren grounds in Nova Scotia. In: Lawrence, J. M. (ed.) Echinoderms: proceedings of the international conference, Tampa Bay Balkema, Rotterdam, p. 277-283

Johnson, P. T (1971). Studies on diseased urchins from Pt. Loma. In: Kelp habitat improvement project annual report, 1 July 1970-30 June 1971. Calif. Inst. Tech., Pasadena, p. $82-90$

Kenner, M. C. (1987). Population ecology of Strongylocentrotus purpuratus inhabiting sublittoral coralline mats within the range of the sea otter in California. MS thesis, Calif. State Univ, Hayward

Lang, C., Mann, K. H. (1976). Changes in sea urchin populations after the destruction of kelp beds. Mar Biol. 36: 321-326 
Laur, D. R, Ebeling, A. W., Coon, D. A. (1988). Effects of sea otter foraging on subtidal reef communities of central California. In: VanBlaricom, G. R., Estes, J. A. (eds.) The community ecology of sea otters. Springer-Verlag, Berlin, p. $151-168$

Lawrence, J. M. (1975). On the relationships between marine plants and sea urchins. Oceanogr mar Biol. A. Rev. 13: $213-286$

Lessios, H. A., Robertson, D. R., Cubit, J. D. (1984). Spread of Diadema mass mortalities through the Caribbean. Science 226: 335-337

Lowry, L.F., Pearse, J. S. (1973). Abalones and sea urchins in an area inhabited by sea otters. Mar Biol. 23: 213-219

Mauzey, K. P., Birkeland, C., Dayton, P. K. (1968). Feeding behavior of asteroids and escape responses of their prey in the Puget Sound region. Ecology 49: 603-619

McClean, J. H. (1962). Sublittoral ecology of kelp beds of the open coast area near Carmel, California. Biol. Bull, mar. biol. Lab., Woods Hole 122: 95-114

Miller, R. J., Colodey, A. G. (1983). Widespread mass mortalities of the green sea urchin in Nova Scotia, Canada. Mar. Biol. 73: 263-267

Moitoza, D. J., Phillips, D. W. (1979). Prey defense, predator preference and non-randomic diet: the interactions between Pycnopodia helianthoides and two species of sea urchins. Mar. Biol. 53: 299-304

Pearse, J. S., Cosa, D. P., Yellin, M. B., Agegian, C. R. (1977) Localized mass mortality of red sea urchins, Strongylocentrotus franciscanus, near Santa Cruz, Calif. Fish. Bull. U.S. 75: 645-648

Pearse, J. S., Hines, A. H. (1979). Expansion of a central California kelp forest following the mass mortality of sea urchins. Mar Biol. 51: 83-91

Pearse, J. S., Hines, A. H. (1987). Long-term population dynamics of sea urchins in a central California kelp forest: rare recruitment and rapid decline. Mar. Ecol. Prog. Ser. 39: $275-283$

Riedman, M. L., Estes, J. A. (1988). A review of the history, distribution, and foraging ecology of sea otters. In: VanBlaricom, G. R., Estes, J. A. (eds.) The community ecology of sea otters. Springer-Verlag, Berlin, p. 4-21

Rosenthal, R. T., Chess, J. R. (1972). A predator-prey relation-

This article was presented by M. S. Foster, Moss Landing, California, USA ship between the leather star, Dermasterias imbricata and the purple urchin Strongylocentrotus purpuratus. Fish. Bull. U.S. 70: 205-216

Rowley, R. J. (1989). Settlement and recruitment of sea urchins Strongylocentrotus spp. in a sea urchin barren ground and a kelp bed: are populations regulated by settlement or post-settlement processes? Mar Biol. 100: 485-494

Scheibling, R. E., Stephenson, R. L. (1984). Mass mortality of Strongylocentrotus droebachiensis (Echinodermata: Echinoidea) off Nova Scotia, Canada. Mar. Biol. 78: 153-164

Scheibling, R. E., Raymond, B. G. (1990). Community dynamics on a subtidal cobble bed following mass mortalities of sea urchins. Mar Ecol. Prog. Ser 63: 127-145

Schiel, D. R., Foster, M.S. (1986). The structure of subtidal algal stands in temperate waters. Oceanogr mar Biol. A. Rev. 24: 265-307

Sokal, R. R., Rohlf, F. J. (1981). Biometry, 2nd edn. Freeman, San Francisco

Tegner, M. J., Dayton, P. K. (1981). Population structure, recruitment and mortality of two sea urchins Strongylocentrotus franciscanus and $S$. purpuratus in a kelp forest. Mar Ecol. Prog. Ser. 5: 255-268

Underwood, A. J. (1981). Techniques of analysis of variance in experimental marine biology and ecology. Oceanogr. mar. Biol. A. Rev. 19: 513-605

VanBlaricom, G. R. (1984). Relationships of sea otters to living marine resources in California: a new perspective. In: Lyle, V. (ed.) Ocean Studies Symposium, Asilomar, CA., Calif. Coast. Comm., Calif. Dept. Fish Game, Sacramento, p. 361-381

VanBlaricom, G. R. (1988). Effects of foraging by sea otters on mussel-dominated intertidal communities. In: VanBlaricom, G. R., Estes, J. A. (eds.) The community ecology of sea otters. Springer-Verlag, Berlin, p. 48-91

Vance, R.R. (1979). Effects of grazing by the sea urchin Centrostephanus coronatus on prey community composition Ecology 60: 537--546

Wilkinson, L. (1988). SYSTAT: the system for statistics. SYSTAT, Inc., Evanston

Winer, B. J. (1971). Statistical principles in experimental design. McGraw Hill, New York

Manuscript first received: August 12, 1990

Revised version accepted: January 9, 1991 